\title{
OPINI AUDIT, TINGKAT KEMANDIRIAN, DAN TIPE PEMERINTAH DAERAH TERHADAP TINGKAT PENGUNGKAPAN INFORMASI
}

\author{
Annisa Murni Prasasti \\ annisamurni95@gmail.com \\ Sri Rahayu \\ Djusnimar Zultilisna \\ Fakultas Ekonomi dan Bisnis, Universitas Telkom
}

\begin{abstract}
This research aims to analyze the effect of the audit opinion, level of independence, and the type of local government to the level of disclosure of information on the official website of the local Government of Central Java province in 2014-2015. Sampling techniques used in this study is a purposive and retrieved samples of as many as 25 local governments. Methods of data analysis used were descriptive and multiple regression. The results showed that the audit opinion, level of independence, and the type of local government effect simultaneously against the level of disclosure of information on the official website of the local government in the province of Central Java. Partially, the audit opinion and the types of local government that have an impact on the level of disclosure of information on the official website of the local government in the province of Central Java. Level of independence has not an impact, partially.
\end{abstract}

Keywords : audit opinion, level of independence, type of local government, level of disclosure information

\begin{abstract}
Abstrak
Penelitian ini bertujuan untuk menganalisis pengaruh opini audit, tingkat kemandirian, dan tipe pemerintah daerah terhadap tingkat pengungkapan informasi pada situs resmi pemerintah daerah di Provinsi Jawa Tengah tahun 2014-2015. Teknik pengambilan sampel menggunakan purposive sampling dan diperoleh sampel sebanyak 25 pemerintah daerah. Metode analisis data yang digunakan dalam penelitian ini adalah analisis statistik deksriptif, uji asumsi klasik, dan analisis regresi berganda. Hasil penelitian menunjukkan bahwa opini audit, tingkat kemandirian, dan tipe pemerintah daerah memiliki pengaruh secara simultan terhadap tingkat pengungkapan informasi pada situs resmi pemerintah daerah di Provinsi Jawa Tengah. Secara parsial, opini audit dan tipe pemerintah daerah yang memiliki pengaruh terhadap tingkat pengungkapan informasi pada situs resmi pemerintah daerah di Provinsi Jawa Tengah. Tingkat kemandirian tidak memiliki pengaruh secara parsial.
\end{abstract}

Kata Kunci : opini audit, tingkat kemandirian, tipe daerah, tingkat pengungkapan informasi pada situs resmi pemerintah daerah 


\section{PENDAHULUAN}

Undang-Undang Nomor 23 Tahun 2014 tentang Pemerintah Daerah, menyatakan bahwa pemerintah daerah merupakan kepala daerah sebagai unsur penyelenggara pemerintahan daerah yang memimpin pelaksanaan urusan pemerintahan yang menjadi kewenangan daerah otonom. Hal tersebut didukung dengan Undang-Undang Dasar Negara Republik Indonesia Tahun 1945 Pasal 18 ayat (2) menurut asas otonomi dan tugas pembantuannya, pemerintah daerah provinsi, kabupaten, dan kota mengatur dan mengurus sendiri urusan pemerintahan. Sejak diberlakukannya Undang-Undang Nomor 23 Tahun 2004 mengenai Otonomi Daerah dimana wewenang atas pengelolaan masing-masing daerah kepada pemerintah kabupaten dan kota di Indonesia, maka pengelolaan pemerintah daerah menjadi semakin penting dalam kehidupan bermasyarakat.

Masyarakat ingin mengetahui bagaimana pengelolaan pemerintah daerah yang dilakukan selama ini. Oleh karena itu, informasi yang diungkapkan pemerintah daerah kepada masyarakat harus jelas. Informasi tersebut berupa informasi keuangan maupun informasi non keuangan yang digunakan untuk menilai kinerja pemerintah daerah dan merupakan pertanggungjawaban pemerintah daerah kepada masyarakat serta pihak ketiga yang memberikan pembiayaan. Pengungkapan informasi dapat dilakukan pemerintah daerah melalui media elektronik yaitu situs resmi (e-government). Hal tersebut didukung dengan adanya Peraturan Menteri Komunikasi dan Informatika Republik Indonesia Nomor 5 Tahun 2015 tentang Registrar Nama Domain Instansi Penyelenggara Negara, pemerintah daerah menggunakan nama domain go.id. Pengungkapan informasi melalui situs resmi sangat efektif dan efisien bagi pengguna informasi, seperti pemerintah, masyarakat, dan investor. Bagi pemerintah, pengungkapan informasi dapat membatu mengevaluasi kinerja yang telah dilaksanakan. Masyarakat dan investor dapat mengakses informasi tentang daerah agar memahami potensi daerahnya sehingga memiliki peluang untuk meningkatkan pendapatan daerah.

Perintah untuk pengungkapan informasi pemerintahan pada situs resmi diatur melalui Peraturan Pemerintah No. 56 Tahun 2005 tentang Sistem Informasi Keuangan Daerah, yang mewajibkan pelaporan informasi keuangan daerah secara berkala melalui dokumen tertulis dan situs resmi pemerintah daerah dengan tujuan untuk melakukan publikasi kepada pengguna informasi. Keterbukaan informasi adalah hak dari pengguna informasi, seperti masyarakat, investor, maupun pemerintah itu sendiri. Hal tersebut juga didukung dengan adanya Instruksi Menteri Dalam Negeri No.188.52/1797/SC/2012 tentang Peningkatan Transparansi Pengelolaan Anggaran Daerah (TPAD) dimana pemerintah daerah harus menyiapkan menu konten dan melakukan publikasi data mutakhir dalam menu konten tersebut pada situs resminya.
Transparansi dan kepercayaan layanan informasi publik yang sesuai dengan kebutuhan masyarakat dapat mendorong tumbuhnya kepercayaan.

Daerah di Provinsi Jawa Tengah telah memenuhi perintah untuk membuat menu konten TPAD dalam situs resmi pemerintah daerah, namun masih ada beberapa pemerintah daerah yang tidak memiliki menu konten tersebut sehingga pengguna informasi kesulitan untuk mendapatkan informasi. Situs resmi pemerintah daerah yang telah menyediakan menu konten ternyata juga masih belum melakukan pengungkapan 12 item yang seharusnya diungkapkan (situs resmi pemerintah daerah). Salah satu item yang masih belum diungkapkan dalam situs resmi adalah satu set Laporan Keuangan Pemerintah Daerah (LKPD) yang up to date. Hal tersebut terbukti karena masih tingginya sengketa informasi mengenai laporan keuangan pemerintah daerah (LKPD) yang menunjukkan bahwa pemerintah daerah masih enggan melakukan keterbukaan informasi publik (www.interface.or.id)

Pengembangan situs resmi pemerintah daerah bertujuan agar masyarakat dapat memperoleh akses informasi dan layanan pemerintah daerah dengan mudah, dan ikut serta untuk berpartisipasi dalam pengembangan demokrasi di Indonesia dengan menggunakan media internet. Pemerintah daerah hendaknya mengembangkan situs resmi dengan isi yang selalu baru, ditulis dengan baik, jelas, dan singkat yang memenuhi kebutuhan pengguna informasi, serta mudah diakses. Sebuah situs resmi pemerintah daerah mempunyai persyaratan minimal untuk isi website tersebut. Sesuai dengan Panduan Penyelenggaraan Situs Web Pemda yang telah diterbitkan Kementerian Komunikasi dan Informasi, situs website pemda diharapkan dapat menyajikan informasi yang sesuai dengan kebutuhan masyarakat sehingga diharapkan dapat dikunjungi dan diminati oleh banyak orang dan merupakan kebanggan tersendiri apabila tidak hanya dibuka oleh masyarakat daerahnya sendiri, melainkan masyarakat seluruh Indonesia bahkan mancanegara. Salah satu paramaternya adalah minimum konten atau isi dan layanan publik. Pada saat ini sudah banyak situs resmi pemerintah daerah yang dapat diakses dengan berbagai macam informasi dan tampilan. Hal tersebut mengakibatkan informasi minimum dan layanan publik yang seharusnya disajikan tetapi tidak tersedia dalam situs resmi pemerintah daerah (situs resmi pemerintah daerah).

Dalam kaitannya dalam pengungkapan informasi baik informasi keuangan dan non keuangan pada situs resmi pemerintah daerah, terdapat faktor-faktor yang mempengaruhi hal tersebut, seperti opini audit. Menurut Undang-Undang Nomor 15 Tahun 2004, opini audit adalah pernyatan profesional sebagai kesimpulan pemeriksa mengenai tingkat kewajaran informasi yang disajikan dalam laporan keuangan. Opini audit adalah informasi yang penting untuk diketahui oleh pengguna informasi, baik pemerintah itu sendiri untuk mengetahui 
kinerja dan melakukan evaluasi, serta masyarakat dan investor untuk meningkatkan kepercayaan kepada pemerintah daerah. Opini audit secara bertingkat terdiri dari Tidak Wajar (TW), Tidak Memberikan Pendapat (TMP), Wajar Dengan Pengecualian (WDP), dan yang terbaik adalah Wajar Tanpa Pengecualian (WTP). Opini audit yang diberikan oleh BPK menunjukkan tingkat kewajaran pada LKPD. Opini audit ditentukan dari beberapa kriteria yang telah ditetapkan BPK seperti kesesuaian dengan SAP dan kecukupan pengungkapan.

Opini audit juga didasarkan kepada pengungkapan informasi yang dilakukan Pemda dalam LKPDnya, apakah sudah sesuai dengan ketentuan perundangundangan terkait pelaporan keuangan daerah. Penelitian yang dilakukan Rahim dan Martani (2012) menyatakan bahwa opini audit berpengaruh pada pengungkapan informasi, baik keuangan maupun non keuangan. Hilmi (2010)juga membuktikan bahwa tingkat penyimpangan keuangan pada temuan audit berpengaruh positif. Menurut berita yang diakses di semarang.bpk.go.id, Jawa Tengah memperoleh opini Wajar Tanpa Pengecualian (WTP), tetapi hasil opini audit tidak dapat diakses sehingga masyarakat tidak dapat mengetahui langsung perolehan opini terhadap pemerintah daerah tersebut.

Adanya otonomi daerah, pemerintah daerah diberi kewenangan yang luas untuk mengelola keuangannya sendiri. Rasio kemandirian keuangan daerah dapat dilihat dari jumlah pendapatan asli daerah (PAD) dibandingkan dengan total pendapatan daerah (TPD) dan bertujuan untuk mengetahui kemampuan pemerintah daerah dalam mengelola keuangan daerah. Tingkat kemandirian dapat menunjukkan kemampuan daerah dalam membiayai kegiatan pemerintahannya sendiri, pembanguan, dan pelayanan kepada masyarakat yang berasal dari pendapatan asli daerah. Provinsi Jawa Tengah memiliki jumlah kabupaten dan kota terbanyak kedua di Pulau Jawa (www.otda.kemendagri.go.id), yaitu enam kota dan dua puluh sembilan (29) kabupaten. Pendapatan Asli Daerah (PAD) yang dihasilkan cukup tinggi, tetapi masih memiliki tingkat kemandirian yang rendah (Laporan Realisasi Anggaran Tahun 2015 Provinsi Jawa Tengah). Hal tersebut menandakan bahwa pendapatan asli daerah belum optimal dan masih memiliki ketergantungan yang tinggi terhadap pemerintah pusat untuk pembiayaan daerah. Menurut penelitian yang dilakukan oleh Rahim dan Martani (2012) tingkat kemandirian tidak memiliki pengaruh terhadap pengungkapan informasi, baik keuangan maupun non keuangan. Namun, menurut penelitian yang dilakukan oleh Puspita (2010) tingkat ketergantungan berpengaruh positif terhadap tingkat pengungkapan dan kualitas informasi dalam situs resmi pemerintah daerah.

Pembagian daerah otonom di Indonesia yaitu pemerintah provinsi disebut sebagai daerah otonom tingkat I, sedangkan pemerintah kabupaten dan kota disebut sebagai daerah otonom tingkat II. Perbedaan kabupaten dan kota terletak pada kondisi geografis dan demografis, seperti aspek ekonomi, sosial, serta budaya. Pada umumnya, kabupaten memiliki daerah yang lebih luas daripada daerah kota tetapi kepadatan penduduknya lebih kecil dan sebagian besar bermata pencaharian di bidang pertanian. Sementara itu daerah kota terdiri dari daerah metropolitan dengan kepadatan penduduk yang lebih tinggi dan umumnya bekerja di bidang perdagangan dan jasa yang lebih modern. Penelitian sebelumnya yang menggunakan faktor tipe daerah yaitu Rahim dan Martani (2012) hasilnya jenis daerah mempengaruhi tingkat pengungkapan informasi keuangan.

Penelitian ini dilakukan untuk mengetahui apakah pemerintah daerah kabupaten dan kota di Provinsi Jawa Tengah yang memiliki situs resmi telah mengungkapkan informasi keuangan, pelayanan dan informasi lainnya dalam situsnya, sehingga informasi tersebut dapat dimanfaatkan oleh pihak-pihak yang mengakses situs resmi tersebut. Hasil penelitian yang dilakukan oleh Puspita (2010) mengatakan bahwa pengungkapan informasi dalam website pemerintah daerah masih tergolong rendah, di bawah level 50\%, yaitu 44.84\%. Selain itu, informasi yang disajikan masih sebatas pada informasi umum daerah. Informasi tentang keuangan dan pembangunan masih sedikit diungkapkan, seperti informasi yang disajikan oleh situs resmi pemerintah daerah di Provinsi Jawa Tengah yang masih belum optimal dan beberapa situs resmi tidak menyajikan informasi keuangan secara up to date karena informasi keuangan yang tersedia adalah informasi beberapa tahun ke belakang, antara 2010-2013. (www.jatengprov.go.id)

Pengungkapan (disclosure) secara konseptual merupakan bagian integral dari pelaporan keuangan. Secara teknis, pengungkapan merupakan langkah akhir dalam proses akuntansi yaitu penyajian informasi dalam bentuk seperangkat penuh statemen keuangan (Suwardjono, 2010:578). Tingkat pengungkapan informasi berkaitan dengan seberapa banyak informasi yang harus diungkapkan, baik kepada pihak internal maupun eksternal. Pengungkapan informasi pada situs resmi pemerintah daerah di Provinsi Jawa Tengah merupakan salah satu bentuk pengungkapan dan pelaksanaan dari e-government di Indonesia.

Pengungkapan informasi baik keuangan maupun non keuangan pada situs resmi pemerintah daerah dapat membantu pemerintah daerah menyampaikan informasi secara cepat, mudah, dan berbiaya rendah. Sementara, pengguna informasi internal seperti pemerintah daerah dan pengguna informasi eksternal, seperti masyarakat dan investor dapat mengakses informasi dengan mudah, dimana saja dan kapan saja. Faktor-faktor seperti opini audit, tingkat kemandirian, dan tipe daerah dapat mempengaruhi tingkat pengungkapan informasi pada situs resmi pemertintah daerah. Semakin bagus kualitas pemerintah maka akan mempengaruhi pemberian opini audit kepada pemerintahan daerah tersebut. Selain itu, tingkat kemandirian juga akan mempengaruhi tingkat pengungkapan informasi pada 
situs resmi pemerintah daerah karena apabila suatu daerah termasuk daerah yang mandiri untuk membiayai kegiatan pemerintahaannya maka daerah tersebut akan melakukan pengungkapan sebagai bentuk transparansi kepada publik. Tipe daerah juga akan berpengaruh karena apabila daerah berbentuk kota yang cenderung lengkap dengan berbagai fasilitas maka akan lebih mudah untuk melakukan pengungkapan. Hal tersebut didukung oleh penelitian yang telah dilakukan oleh Rahim dan Martani (2012) yang menyebutkan bahwa opini audit, tingkat kemandirian, dan tipe daerah berpengaruh terhadap pengungkapan informasi keuangan pada website pemda.

Opini audit merupakan salah satu indikator akuntabilitas terhadap sebuah laporan keuangan. Opini audit diberikan oleh Badan Pemeriksa Keuangan Republik Indonesia (BPK RI) yang menunjukkan tingkat kewajaran terhadap suatu Laporan Keuangan Pemerintah Daerah (LKPD). Tingkat kewajaran yang diberikan merupakan jenis opini audit yang diberikan, yaitu mulai tingkat kewajaran yang sangat baik hingga buruk. Opini Wajar Tanpa Pengecualian (WTP) adalah opini yang yang paling baik, kemudian Wajar Dengan Pengecualian (WDP), Tidak Wajar (TW), dan Tidak Memberikan Pendapat (TMP).

Apabila tingkat materialitas rendah dalam LKPD maka pemerintah daerah akan mendapatkan opini yang baik atau tingkat kewajarannya tinggi. Apabila suatu pemerintah daerah mendapatkan pendapat atau opini audit yang baik maka akan melakukan pengungkapan informasi kepada publik sehingga dapat menarik investor dan meningkatkan kepercayaan masyarakat terhadap pengelolaan daerah tersebut. Hal tersebut didukung oleh penelitian Rahim dan Martani (2012) yang menyatakan bahwa opini audit berpengaruh terhadap tingkat pengungkapan informasi pada website pemerintah daerah di Indonesia. Penelitian Chen, et.al (2015) juga mengungkapkan bahwa opini audit berpengaruh terhadap tingkat pengungkapan informasi.

Tingkat kemandirian daerah adalah kemampuan sebuah daerah untuk melaksanakan pemerintahannya. Di Indonesia, pelaksanaan pemerintah daerah sebagian besar masih bergantung pada dana yang diberikan oleh pemerintah pusat. Akan tetapi setiap daerah memiliki potensi-potensi masing-masing yang dapat digali dan dikembangkan sehingga menghasilkan sumber pendapatan asli daerah (PAD), termasuk Provinsi Jawa Tengah. Pendapatan Asli Daerah (PAD) digunakan sebagai salah satu indikator kinerja pemerintah daerah. Jawa Tengah memiliki jumlah kabupaten dan kota terbanyak kedua di Indonesia, maka Jawa Tengah harus dapat mengembangkan potensi yang dimiliki agar dapat melaksanakan pemerintahannya dengan baik. Semakin tinggi tingkat kemandirian maka pemerintah daerah akan lebih terbuka dalam melakukan pengungkapan informasi. Pengungkapan dilakukan agar publik mengetahui dan mempercayai bahwa pemerintahan daerah tersebut telah dapat berjalan dengan baik.
Penelitian sebelumnya telah dilakukan oleh Mustika dan Martani (2012), hasilnya adalah kemandirian daerah berpengaruh terhadap tingkat pengungkapan informasi keuangan dan non keuangan pada situs pemerintah daerah di Indonesia.

Di Indonesia, daerah otonom dibagi menjadi dua, yaitu daerah otonom I adalah provinsi, dan daerah otonom II adalah kabupaten atau kota. Kabupaten atau kota memiliki perbedaan dari sudut pandang demografis dan geografisnya. Kabupaten biasanya terdiri dari daerah pedesaan yang memiliki daerah yang lebih luas jika dibandingkan daerah kota. Akan tetapi, kepadatan penduduknya akan lebih banyak di kota. Karakteristik yang berbeda antara kabupaten dan kota dapat menyebabkan perbedaan tingkat pengungkapan informasi pada situs resmi pemerintah daerah. Penduduk kota yang pada umumnya memiliki wawasan yang luas akan lebih kritis terhadap pelaksanaan pemerintahan. Oleh sebab itu, pemerintahan yang berbentuk kota cenderung melakukan tingkat pengungkapan informasi yang lebih tinggi dibandingkan pemerintah kabupaten.

Penelitian yang mendukung adalah penelitian Laswad, et.al (2005) yang memasukkan jenis daerah sebagai salah satu variabel yang akan diuji. Hasilnya adalah daerah kota memiliki tigkat pengungkapan informasi keuangan pada website yang lebih tinggi daripada kabupaten. Maria, et.al (2010) juga mengungkapkan bahwa jenis entitas berpengaruh pada tingkat pengungkapan laporan tahunan sektor publik. Di Indonesia, penelitian dilakukan Rahim dan Martani (2012) yang menyatakan bahwa jenis daerah berpengaruh positif terhadap tingkat pengungkapan informasi pada situs resmi pemerintah daerah di Indonesia.

Hipotesis merupakan jawaban sementara terhadap rumusan masalah penelitian, dimana rumusan masalah penelitian telah digunakan dalam bentuk kalimat pertanyaan (Sugiyono, 2014:70). Berdasarkan teori dan kerangka pemikiran yang telah dijelaskan, maka penelitian ini memiliki hipotesis sebagai berikut : (1) Opini audit, tingkat kemandirian daerah, dan tipe daerah berpengaruh positif signifikan secara simultan terhadap tingkat pengungkapan informasi baik informasi keuangan maupun non keuangan pada situs resmi pemerintah daerah di Provinsi Jawa Tengah tahun 20142015. (2) Opini audit berpengaruh positif signifikan secara parsial terhadap tingkat pengungkapan informasi baik informasi keuangan maupun non keuangan pada situs resmi pemerintah daerah di Provinsi Jawa Tengah tahun 2014-2015. (3) Tingkat kemandirian daerah berpengaruh positif signifikan secara parsial terhadap tingkat pengungkapan informasi baik informasi keuangan maupun non keuangan pada situs resmi pemerintah daerah di Provinsi Jawa Tengah tahun 20142015. (4) Tipe daerah berpengaruh positif signifikan secara parsial terhadap tingkat pengungkapan informasi baik informasi keuangan maupun non keuangan pada 
situs resmi pemerintah daerah di Provinsi Jawa Tengah tahun 2014-2015.

Menurut Sekaran (2014:115) variabel penelitian adalah segala sesuatu yang berbentuk apa saja yang ditetapkan oleh peneliti untuk dipelajari sehingga diperoleh informasi tentang hal tersebut, kemudian ditarik kesimpulannya. Variabel pada peneitian ini menggunakan variabel independen dan variabel dependen.

Variabel independen atau variabel bebas merupakan variabel yang mempengaruhi atau yang menjadi sebab perubahannya atau timbulnya variabel dependen (terikat) (Sekaran, 2014:117) Variabel independen yang digunakan dalam penelitian ini adalah opini audit, tingkat kemandirian daerah, dan tipe daerah.

Opini menurut Undang-Undang No. 15 Tahun 2004 adalah pernyataan profesional sebagai kesimpulan pemeriksa mengenai tingkat kewajaran informasi (keuangan) yang disajikan dalam laporan keuangan. Opini audit diberikan berdasarkan kriteria kesesuaian dengan standar akuntansi pemerintahan, kecukupan pengungkapan (adequate disclosures), kepatuhan terhadap peraturan perundang-undangan, dan efektivitas sistem pengendalian intern. Berdasarkan kriteria tersebut, maka opini audit diukur dari perolehan opini yang diperoleh pemerintah daerah di Provinsi Jawa Tengah menggunakan variabel dummy, yaitu mendapatkan nilai 1 apabila pemerintah daerah mendapatkan opini Wajar Tanpa Pengecualian (WTP) dan nilai 0 apabila Opini Wajar Dengan Pengecualian (WDP).

Undang-Undang Nomor 32 Tahun 2004 menyatakan bahwa kemandirian keuangan daerah berarti pemerintah dapat melakukan pembiayaan dan pertanggungjawaban keuangan sendiri, melaksanakan sendiri, dalam rangka asas desentralisasi. Menurut Abdul Halim (2013) kemandirian keuangan daerah adalah kemampuan pemerintah daerah dalam membiayai sendiri kegiatan pemerintahan, pembangunan, dan pelayanan kepada masyarakat yang telah membayar pajak dan retribusi sebagai sumber pendapatan yang diperlukan daerah. Abdul Halim (2013) menyatakan bahwa kemandirian keuangan daerah sendiri ditunjukkan oleh besar kecilnya pendapatan asli daerah dibandingkan dengan pendapatan daerah yang berasal dari pendapatan asli daerah dan sumber lain seperti bantuan pemerintah pusat. Hal tersebut dapat diukur dengan menggunakan rumus seperti berikut :

$$
\begin{gathered}
\text { Rasio } \\
\text { Kemandirian }
\end{gathered}=\frac{\text { Pendapatan Asli Daerah (PAD) }}{\text { Total Pendapatan Daerah (TPD) }} \times 100 \%
$$

Negara Kesatuan Republik Indonesia dibagi atas daerah-daerah provinsi dan daerah provinsi itu dibagi atas kabupaten dan kota, yang tiap-tiap provinsi, kabupaten dan kota itu mempunyai pemerintahan daerah, yang diatur dengan undang-undang (Pasal
18 Ayat (1) UUD 1945). Pembentukan daerah adalah penetapan status daerah pada wilayah tertentu. Berdasarkan Undang-Undang Nomor 23 Tahun 2004 Pasal 2, daerah provinsi dan kabupaten atau kota merupakan daerah dan masing-masing mempunyai pemerintahan daerah. Daerah provinsi selain berstatus sebagai daerah juga merupakan wilayah administratif yang menjadi wilayah kerja bagi gubernur sebagai wakil pemerintah pusat dan wilayah kerja bagi gubernur dalam menyelenggarakan urusan pemerintahan umum di wilayah daerah provinsi. Daerah kabupaten atau kota selain berstatus sebagai daerah juga merupakan wilayah administratif yang menjadi wilayah kerja bagi bupati atau wali kota dalam menyelenggarakan urusan pemerintahan umum di wilayah daerah kabupaten atau kota. Penelitian ini menggunakan daerah kota atau kabupaten yang diukur dengan variabel dummy, yaitu memberikan nilai 1 untuk daerah kota dan nilai 0 untuk daerah kabupaten.

Variabel dependen atau variabel terikat menurut Sugiyono (2013:61) merupakan variabel yang dipengaruhi atau yang menjadi akibat karena adanya variabel bebas. Variabel dependen yang digunakan dalam penelitian ini adalah tingkat pengungkapan informasi pada situs resmi pemerintah daerah. Menurut Evans (dalam Suwardjono, 2010:581), luas pengungkapan berkaitan dengan masalah seberapa banyak informasi yang harus diungkapkan, disebut dengan tingkat pengungkapan (levels of disclosure). Tingkat pengungkapan dalam penelitian ini terdiri dari tingkat pengungkapan informasi keuangan dan informasi non keuangan yang terdapat pada situs resmi pemerintah daerah.

Tingkat pengungkapan informasi keuangan diukur dari indeks pengungkapan keuangan yang dilihat dari data mutakhir menu konten Transaparansi Pengelolaan Anggaran Daerah (TPAD) dan Laporan Keuangan Pemerintah Daerah (LKPD) yang ada pada situs resmi pemerintah daerah. Laporan keuangan yang harus disajikan pemerintah daerah berdasarkan Peraturan Pemerintah Nomor 71 Tahun 2010 adalah sebagai berikut : (a) Laporan Realisasi Anggaran APBD, (b) Neraca, (c) Laporan Arus Kas, (d) Catatan atas Laporan Keuangan (CALK).

Data mutakhir menu konten TPAD berdasarkan Instruksi Menteri Dalam Negeri Republik Indonesia Nomor 188.52/1797/SJ tentang Peningkatan Transparansi Pengelolaan Anggaran Daerah meliputi: (a) Ringkasan Rencana Kerja dan Anggaran Satuan Kerja Perangkat Daerah dan Ringkasan Rencana Kerja dan Anggaran Pejabat Pengelola Keuangan Daerah, (b) Rancangan Peraturan Daerah tentang Anggaran Pendapatan dan Belanja Daerah dan Rancangan Peraturan Daerah tentang Perubahan Anggaran Pendapatan dan Belanja Daerah yang disampaikan Kepala Daerah kepada Dewan Perwakilan Rakyat Daerah, (c) Peraturan Daerah tentang Anggaran 
Pendapatan dan Belanja Daerah dan Peraturan Daerah tentang Perubahan Anggaran Pendapatan dan Belanja Daerah yang disampaikan Kepala Daerah kepada Dewan Perwakilan Rakyat Daerah, (d) Ringkasan Dokumen Pelaksanaan Anggaran Satuan Kerja Perangkat Daerah dan Ringkasan Dokumen Pelaksanaan Anggaran Pejabat Pengelola Keuangan Daerah, (e) Laporan Realisasi Anggaran seluruh Satuan Kerja Perangkat Daerah Pengelola Keuangan Daerah, (f) Laporan Keuangan Pemerintah Daerah yang sudah diaudit dan opini atas Laporan Keuangan Pemerintah Daerah.

Informasi non keuangan diukur dari indeks pengungkapan non keuangan yang terdapat dalam Panduan Pengembangan Website Pemda (2010) yang menyebutkan konten minimum yang harus dilaporkan adalah sebagai berikut: (a) Selayang Pandang, (b) Pemerintah Daerah, (c) Geografi, (d) Peta Wilayah dan Sumber Daya, (e) Peraturan/kebijakan daerah, (f) Berita, (g) Forum diskusi, (h) Saran/Komentar pengunjung pada buku tamu.

Selain itu tingkat pengungkapan informasi non keuangan juga diukur berdasarkan Peraturan Pemerintah Nomor 38 Tahun 2007 tentang Pembagian Urusan Pemerintahan, dimana terdapat 26 urusan wajib yang harus diselenggarakan pemerintah daerah berkaitan dengan pelayanan dasar.

Tingkat pengungkapan informasi diukur dengan cara melakukan checklist terhadap item yang diungkapkan pada situs resmi pemerintah daerah kemudian menjumlah seluruh item pengungkapan dan membandingkan dengan item yang seharusnya diungkapkan.

\section{METODE}

Operasionalisasi variabel penelitian ditunjukkan pada Tabel 1. Populasi penelitian adalah situs resmi pemerintah daerah di Provinsi Jawa Tengah tahun 2014-2015. Teknik pengambilan sampel menggunakan purposive sampling, yaitu teknik pengambilan sampel dengan pertimbangan tertentu.

Berikut ini adalah kriteria pengambilan sampel yang digunakan :
Tabel 2. Kriteria Pengambilan Sampel

\begin{tabular}{llc}
\hline No & \multicolumn{1}{|c}{ Kriteria Pengambilan Sampel } & $\begin{array}{c}\text { Total } \\
\text { Pemerintah } \\
\text { Daerah }\end{array}$ \\
\hline 1. & $\begin{array}{l}\text { Situs resmi pemerintah daerah di } \\
\text { Provinsi Jawa Tengah yang terdaftar } \\
\text { pada Kementerian Dalam Negeri }\end{array}$ & 35 \\
2. $\quad \begin{array}{l}\text { Situs resmi pemerintah daerah di Provinsi } \\
\text { Jawa Tengah yang tidak dapat diakses }\end{array}$ & $(0)$ \\
3. $\quad \begin{array}{l}\text { Situs resmi pemerintah daerah di Provinsi } \\
\text { Jawa Tengah yang tidak mengungkapkan } \\
\text { laporan keuangan pemerintah daerah } \\
\text { tahun 2014-2015 pada situs resmi }\end{array}$ & $(10)$ \\
\hline & $\begin{array}{l}\text { Jumlah Sampel } \\
\text { Jumlah Tahun }\end{array}$ \\
\hline & Total Sampel & 25 \\
\hline
\end{tabular}

Sumber : Data sekunder yang telah diolah, 2017

Metode yang digunakan pada penelitian ini adalah analisis statistik deskriptif dan analisis regresi berganda. Rumus regresi berganda pada penelitian ini sebagai berikut :

$$
\mathrm{Y}=\alpha+\beta_{1} \mathrm{X}_{1}+\beta_{2} \mathrm{X}_{2}+\beta_{3} \mathrm{X}_{3}+\mathrm{e}
$$

Y = Tingkat Pengungkapan Informasi pada Situs Resmi Pemerintah Daerah

$=$ Konstanta

$\alpha \quad \beta_{1}, \beta_{2}, \beta_{3}=$ Koefisien Regresi

$\mathrm{X}_{1}=$ Opini Audit

$\mathrm{X}_{2} \quad=$ Tingkat Kemandirian

$\mathrm{X}_{3} \quad=$ Tipe Daerah

$\mathrm{e}=$ Error

Pengujian hipotesis yang digunakan dalam penelitian ini adalah uji asumsi klasik dan uji hipotesis secara simultan (uji F) dan uji secara parsial (uji t). Uji asumsi klasik digunakan untuk mengetahui apakah model regresi yang digunakan dalam penelitian menunjukkan hubungan yang signifikan. Uji asumsi klasik yang dilakukan yaitu uji normalitas, multikolinearitas, heteroskedastisitas, dan uji autokorelasi (Ghozali, 2011).

Tabel 1. Operasionalisasi Variabel

\begin{tabular}{|c|c|c|c|c|}
\hline No & Variabel & Konsep Variabel & Indikator & Skala \\
\hline 1 & Opini Audit & $\begin{array}{l}\text { Opini adalah pernyataan profesional sebagai } \\
\text { kesimpulan pemeriksa mengenai tingkat } \\
\text { kewajaran informasi (keuangan) yang } \\
\text { disajikan dalam laporan keuangan. (UU } \\
\text { No.15 Tahun 2004) }\end{array}$ & $\begin{array}{l}\text { Menggunakan variabel dummy, } \\
1 \quad=\text { opini Wajar Tanpa Pengecualian (WTP) } \\
0 \quad=\text { opini Wajar Dengan Pengecualian (WDP) }\end{array}$ & Nominal \\
\hline
\end{tabular}




\begin{tabular}{|c|c|c|c|c|c|}
\hline 2 & $\begin{array}{l}\text { Tingkat Kemandirian } \\
\text { Daerah }\end{array}$ & $\begin{array}{l}\text { Kemandirian keuangan daerah adalah } \\
\text { kemampuan pemerintah daerah dalam } \\
\text { membiayai sendiri kegiatan pemerintahan, } \\
\text { pembangunan, dan pelayanan kepada } \\
\text { masyarakat yang telah membyar pajak dan } \\
\text { retribusi sebagai sumber pendapatan yang } \\
\text { diperlukan daerah (Halim, 2013) }\end{array}$ & $\underset{\text { Kemandirian }}{\text { Rasio }}=$ & $\frac{\text { Pendapatan Asli Daerah }}{\text { Total Pendapatan Daerah }}$ & Rasio \\
\hline 3 & Tipe Daerah & $\begin{array}{l}\text { Negara Kesatuan Republik Indonesia dibagi } \\
\text { atas daerah-daerah provinsi dan daerah } \\
\text { provinsi itu dibagi atas kabupaten dan kota, } \\
\text { yang tiap-tiap provinsi, kabupaten dan kota } \\
\text { itu mempunyai pemerintahan daerah, yang } \\
\text { diatur dengan undang-undang (Pasal } 18 \text { Ayat } \\
\text { (1) UUD 1945) }\end{array}$ & \multicolumn{2}{|c|}{$\begin{array}{l}\text { Menggunakan variabel dummy, } \\
1=\text { pemerintahan kota } \\
0=\text { pemerintahan kabupaten }\end{array}$} & Nominal \\
\hline 4 & $\begin{array}{l}\text { Tingkat Pengungkapan } \\
\text { Informasi keuangan } \\
\text { dan non keuangan }\end{array}$ & $\begin{array}{l}\text { Luas pengungkapan berkaitan dengan } \\
\text { masalah seberapa banyak informasi yang } \\
\text { harus diungkapkan, disebut dengan tingkat }\end{array}$ & \multicolumn{2}{|c|}{$\begin{array}{l}\text { Item informasi keuangan dan non keuangan } \\
\text { yang diungkapkan pada situs resmi pemerintah } \\
\text { daerah }\end{array}$} & Rasio \\
\hline & $\begin{array}{l}\text { pada Situs Resmi } \\
\text { Pemerintah Daerah }\end{array}$ & $\begin{array}{l}\text { pengungkapan (levels of disclosure). } \\
\text { Suwadjono (2010:581) }\end{array}$ & \multicolumn{2}{|c|}{$\begin{array}{l}\text { Item informasi keuangan dan non keuangan } \\
\text { yang seharusnya diungkapkan }\end{array}$} & \\
\hline
\end{tabular}

\section{HASIL}

Tabel 3 adalah hasil statistik deskriptif setiap variabel.

Tabel 3. Hasil Statistik Deskriptif Descriptive Statistics

\begin{tabular}{lccccc}
\hline & $\mathrm{N}$ & Minimum & Maximum & Mean & $\begin{array}{c}\text { Std. } \\
\text { Deviation }\end{array}$ \\
\hline Opini Audit & 50 & .00 & 1.00 & .3600 & .48487 \\
$\begin{array}{l}\text { Tingkat } \\
\text { Kemandirian }\end{array}$ & 50 & .00 & 23.90 & 13.889 & 3.72987 \\
$\begin{array}{l}\text { Tipe Daerah } \\
\text { Tingkat }\end{array}$ & 50 & .00 & 1.00 & .0800 & .27405 \\
$\begin{array}{l}\text { Pengungkapan } \\
\text { Informasi }\end{array}$ & 50 & 35.42 & 89.58 & 63.375 & 11.99392 \\
$\begin{array}{l}\text { Valid N } \\
\text { (listwise) }\end{array}$ & 50 & & & & \\
\hline
\end{tabular}

Sumber : Hasil Pengolahan SPSS 20, 2017

Rumus regresi linear berganda pada penelitian ini adalah sebagai berikut :

Tingkat pengungkapan informasi $=57.478+0.065$ Opini Audit +0.352 Tingkat Kemandirian +15.492 Tipe Daerah + e

Jika nilai variabel independen 0 maka tingkat pengungkapan pada situs resmi pemerintah daerah adalah 57.478\%. Koefisien opini audit sebesar 0.065 artinya jika opini audit mengalami kenaikan sebesar 1 dan nilai variabel lain tetap maka tingkat pengungkapan pada situs resmi pemda naik sebesar 0.065 . Koefisien tingkat kemandirian sebesar 0.0352 artinya jika tingkat kemandirian mengalami kenaikan sebesar 1 dan nilai variabel lain tetap maka tingkat pengungkapan pada situs resmi pemda naik sebesar 0.0352 . Koefisien tipe daerah sebesar 15.492 artinya jika tipe daerah mengalami kenaikan sebesar 1 dan nilai variabel lain tetap maka tingkat pengungkapan pada situs resmi pemda naik sebesar 15.492 .

Uji hipotesis dilakukan dengan menggunakan uji asumsi klasik dan tidak ditemukan permasalahan dalam pengujian. Selanjutnya dilakukan uji hipotesis secara simultan (uji F). Berikut hasil uji hipotesis secara simultan (Uji F) pada penelitian ini :

Tabel 4. Uji Simultan (Uji F)

\begin{tabular}{lcccccc}
\hline \multicolumn{7}{c}{ ANOVA $^{\text {a }}$} \\
\hline \multirow{2}{*}{ Model } & $\begin{array}{c}\text { Sum of } \\
\text { Squares }\end{array}$ & df & $\begin{array}{c}\text { Mean } \\
\text { Square }\end{array}$ & F & Sig. \\
\hline 1 & Regression & 1291.988 & 3 & 430.663 & 3.441 & $.024^{\mathrm{b}}$ \\
& Residual & 5756.867 & 46 & 125.149 & & \\
& Total & 7048.855 & 49 & & & \\
\hline
\end{tabular}

a. Dependent Variable: Tingkat Pengungkapan Informasi

b. Predictors: (Constant), Tipe Pemerintah Daerah, Opini Audit, Tingkat Kemandirian Sumber : Hasil Pengolahan SPSS, 2017

Berdasarkan Tabel 4, nilai signifikansi sebesar $0.024<$ 0.05 artinya bahwa opini audit, tingkat kemandirian, dan tipe daerah berpengaruh positif signifikan secara bersama-sama (simultan) terhadap tingkat pengungkapan informasi pada situs resmi pemerintah daerah di Provinsi Jawa Tengah. 
Berikut hasil uji hipotesis secara parsial (uji t) :

Tabel 5. Uji Parsial (Uji t)

\begin{tabular}{|c|c|c|c|c|c|c|}
\hline \multicolumn{7}{|c|}{ Coefficients $^{\mathrm{a}}$} \\
\hline & \multirow[t]{2}{*}{ Model } & \multicolumn{2}{|c|}{$\begin{array}{c}\text { Unstandardized } \\
\text { Coefficients }\end{array}$} & \multirow{2}{*}{$\begin{array}{c}\begin{array}{c}\text { Standardized } \\
\text { Coefficients }\end{array} \\
\text { Beta }\end{array}$} & \multirow[t]{2}{*}{$\mathrm{t}$} & \multirow[t]{2}{*}{ Sig. } \\
\hline & & B & $\begin{array}{l}\text { Std. } \\
\text { Error }\end{array}$ & & & \\
\hline \multirow[t]{4}{*}{1} & (Constant) & 57.478 & 7.141 & & 8.049 & .000 \\
\hline & $\begin{array}{l}\text { Opini } \\
\text { Audit }\end{array}$ & .065 & 3.313 & .027 & .199 & .043 \\
\hline & $\begin{array}{l}\text { Tingkat } \\
\text { Kemandirian }\end{array}$ & .362 & .552 & .110 & .675 & .503 \\
\hline & $\begin{array}{l}\text { Tipe } \\
\text { Daerah }\end{array}$ & 15.492 & 7.125 & .354 & 2.174 & .035 \\
\hline
\end{tabular}

a. Dependent Variable: Tingkat Pengungkapan

Sumber : Hasil Pengelohan SPSS, 2017

\section{PEMBAHASAN}

Hasil dari uji deskriptif dalam Tabel 3 menunjukkan bahwa jumlah sampel (n) sebanyak 50 daerah kabupaten dan kota. Opini audit memiliki nilai minimum 0 dan nilai maksimum 1 karena menggunakan variabel dummy dalam pengukuran variabelnya. Kota dan kabupaten di Provinsi Jawa Tengah mendapatkan opini audit Wajar Tanpa Pengecualian dan Wajar Dengan Pengecualian dari Badan Pemeriksa Keuangan Republik Indonesia (BPK-RI). Nilai 1 diberikan kepada daerah yang mendapatkan opini Wajar Tanpa Pengecualian (WTP) dan nilai 0 diberikan kepada daerah yang mendapatkan opini Wajar Dengan Pengecualian (WDP). Opini audit memiliki nilai rata-rata (mean) 0.36 atau $36 \%$ dari total sampel daerah di Provinsi Jawa Tengah mendapatkan opini wajar tanpa pengecualian selama tahun 20142015. Standar deviasi opini audit adalah sebesar 0.48487 yang artinya bahwa sebagian besar data memiliki jarak sebesar 0.48487 dari nilai rata-rata (mean). Nilai standar deviasi lebih besar daripada nilai rata-rata menunjukkan bahwa data tersebut bervariasi atau tidak berkelompok.

Variabel tingkat kemandirian memiliki nilai minimum 0.00 dan nilai maksimum $23.90 \%$, artinya tingkat pendapatan asli daerah paling besar di Provinsi Jawa Tengah sebesar $23.90 \%$ dari total pendapatan daerahnya. Nilai rata-rata (mean) tingkat kemandirian yaitu sebesar $13.89 \%$ yang berarti bahwa tingkat kemandirian daerah di Provinsi Jawa Tengah ratarata sebesar $13.89 \%$ dan menunjukkan daerah yang memiliki kemandirian yang kurang untuk membiayai kegiatan pemerintahaan sehingga masih memiliki ketergantungan dengan pihak lain, seperti pemerintah provinsi dan pemerintah pusat. Daerah di Provinsi Jawa Tengah rata-rata hanya memiliki pendapatan asli daerah (PAD) sebesar $13.89 \%$ dari total pendapatan yang diperoleh. Tingkat kemandirian memiliki standar deviasi 3.72987 yang menandakan bahwa sebagian besar data memiliki jarak sebesar 3.72987 dari nilai ratarata (mean). Nilai standar deviasi lebih kecil daripada nilai rata-rata menandakan bahwa data tersebut tidak bervariasi atau berkelompok.

Tipe daerah memiliki nilai maksimum 1.00 dan nilai minimum 0.00 karena menggunakan variabel dummy dalam pengukurannya. Nilai 1 diberikan kepada tipe daerah kota dan 0 untuk daerah tipe daerah kabupaten. Hal tersebut dikarenakan Provinsi Jawa Tengah memiliki pembagian daerah kota dan kabupaten di bawah pemerintahan Provinsi. Nilai rata-rata (mean) tipe daerah adalah 0.08 yang menadakan bahwa hanya sebesar $8 \%$ dari total sampel (n) yang memiliki nilai 1 atau daerah dengan tipe kota. Tipe daerah memiliki standar deviasi sebesar 0.274 artinya adalah sebagian besar data yang terdistribusi memiliki jarak sebesar 0.274 dari nilai rata-ratanya. Standar deviasi memiliki nilai yang lebih besar daripada nilai rata-rata tipe daerah menandakan bahwa data tersebut bervariasi atau tidak berkelompok.

Variabel tingkat pengungkapan yang diukur dari pengungkapan informasi keuangan dan non keuangan memiliki nilai minimum $35.42 \%$ dan nilai maksimum $89.58 \%$, artinya daerah di Provinsi Jawa Tengah melakukan pengungkapan informasi pada situs resmi pemerintah daerah paling rendah yaitu $35.42 \%$ dari total item pengungkapan yang seharusnya dan paling tinggi $89.58 \%$ dari total item pengungkapan yang seharusnya diungkapkan.. Nilai rata-rata (mean) sebesar $63.38 \%$ yang bearti bahwa daerah di Provinsi Jawa Tengah melakukan pengungkapan informasi keuangan dan non keuangan pada situs resmi pemerintah daerah sebesar $63.38 \%$ dari total item pengungkapan sebanyak 48 item. Standar deviasi tingkat pengungkapan yaitu sebesar 11.994 yang berarti bahwa sebagian besar data yang terdistribusi memiliki jarak 11.994 dari nilai rata-rata (mean). Nilai standar deviasi memiliki nilai yang lebih kecil dari nilai rata-rata yang menunjukkan bahwa data tersebut berkelompok atau tidak bervariasi.

Variabel opini audit memiliki koefisien 0.065 dengan nilai probabilitas signifikansi $0.043<0.05$. Hal tersebut menunjukkan bahwa variabel opini audit memiliki pengaruh positif signifikan secara parsial terhadap tingkat pengungkapan informasi pada situs resmi pemerintah daerah di Provinsi Jawa Tengah. Hal ini berarti semakin tinggi nilai opini audit maka tingkat pengungkapan informasi akan semakin besar. Pemerintah daerah yang memiliki opini audit yang bagus berarti memiliki pelaporan dan pelaksanaan keuangan yang baik dan cenderung tidak akan menutupi informasi pelaksanaan yang baik ini. Pengungkapan informasi keuangan pada situs resmi yang memiliki opini audit yang bagus akan menjadi sinyal positif bagi masyarakat terhadap pemerintah daerahnya. Sehingga akan mendorong terciptanya transparansi informasi kepada publik yang dilakukan oleh pemerintah daerah. 
Hal ini sejalan dengan penelitian terdahulu yang dilakukan Rahim dan Martani (2012)[11] dan Chen et.al (2015)[3] yang menyatakan bahwa opini audit memiliki pengaruh positif signifikan terhadap tingkat pengungkapan informasi.

Variabel tingkat kemandirian memiliki koefisien 0.362 dengan nilai probabilitas signifikansi $0.503>$ 0.05 . Hal tersebut menunjukkan bahwa variabel tingkat kemandirian tidak memiliki pengaruh positif signifikan secara parsial terhadap tingkat pengungkapan informasi pada situs resmi pemerintah daerah di Provinsi Jawa Tengah. Semakin tinggi rasio tingkat kemandirian pemerintah daerah menunjukkan semakin mandiri pemerintah daerah membiayai sendiri kegiatan pemerintahan, pembangunan, dan pelayanan kepada masyarakat sehingga ketergantungan terhadap pihak eksternal menjadi rendah. Hal inilah yang membuat pemerintah daerah tidak termotivasi untuk meningkatkan pengungkapan informasi baik keuangan maupun non keuangan karena rendahnya tuntutan transparansi dan akuntabilitas dari pihak eksternal. Selain itu, pada penelitian ini tingkat pengungkapan informasi yang digunakan adalah informasi keuangan dan non keuangan. Oleh sebab itu, tingkat kemandirian tidak berpengaruh terhadap tingkat pengungkapan informasi karena tingkat kemandirian cenderung dilihat dari sisi keuangan karena diukur menggunakan perbandingan pendapatan asli daerah dengan total pendapatan daerah. Penelitian ini sesuai dengan penelitian Arik et.al (2014) dan Hilmi (2010) yang menyatakan bahwa tingkat kemandirian tidak berpengaruh terhadap tingkat pengungkapan informasi.

Variabel tipe daerah memiliki koefisien 15.492 dengan nilai probabilitas signifikansi $0.035<0.05$. Hal tersebut menunjukkan bahwa variabel opini audit memiliki pengaruh positif signifikan secara parsial terhadap tingkat pengungkapan informasi pada situs resmi pemerintah daerah di Provinsi Jawa Tengah. Hal ini berarti bahwa tipe daerah yang semakin tinggi, kota maka tingkat pengungkapan informasi semakin naik. Pemerintah daerah yang berbentuk kota memiliki struktur daerah dan karakteristik penduduk yang berbeda dengan pemerintah kabupaten. Kondisi lingkungan yang lebih modern dan lingkungan ekonomi yang lebih baik dapat meningkatkan tingkat kepedulian masyarakat akan pelaksanaan pemerintahan. Hal tersebut akan mendorong permintaan akan informasi pelaksanaan pemerintah sebagai bentuk pengawasan publik menjadi lebih besar dibandingkan dengan daerah kabupaten. Hasil penelitian ini sejalan dengan penelitian yang telah dilakukan Rahim dan Martani (2012), Rahman dkk (2013), dan Arik et.al (2014) yang menyatakan bahwa tipe daerah berpengaruh terhadap tingkat pengungkapan informasi.

\section{KESIMPULAN}

Berdasarkan hasil analisis data yang telah dilakukan, maka dapat disimpulkan bahwa variabel opini audit, tingkat kemandirian, dan tipe daerah mempunyai pengaruh positif yang signifikan secara simultan atau bersama-sama terhadap tingkat pengungkapan informasi pada situs resmi pemerintah daerah di Provinsi Jawa Tengah periode tahun 2014-2015. Opini audit dan tipe daerah memiliki pengaruh positif signifikan secara parsial terhadap tingkat pengungkapan informasi pada situs resmi pemerintah daerah di Provinsi Jawa Tengah tahun 2014-2015, sedangkan tingkat kemandirian tidak memiliki pengaruh signifikan.

Bagi peneliti selanjutnya dapat menambah jumlah daerah di berbagai Provinsi di Indonesia sebagai sampel agar lebih mengetahui tingkat pengungkapan informasi pada situs resmi pemerintah daerah di Indonesia. Selain itu, dapat menambah variabel-variabel lain yang mempengaruhi tingkat pengungkapan, seperti leverage, tingkat investasi sehingga diperoleh hasil yang lebih komprehensif. Bagi Pemerintah daerah di Provinsi Jawa Tengah diharapkan dapat fokus untuk dapat meningkatkan perolehan opini audit Wajar Tanpa Pengecualian (WTP). Pemerintah daerah kabupaten di Provinsi Jawa Tengah harus memiliki peningkatan di aspek sosial, budaya, ekonomi agar setara dengan kota sehingga dapat melakukan pengungkapan informasi pada situs resmi pemerintah daerah. Sebagai regulator perlu menegaskan peraturan mengenai pengungkapan informasi, baik informasi keuangan maupun non keuangan pada situs resmi pemerintah daerah karena dapat meningkatkan transparansi dan akuntabilitas pemerintah daerah melaui media yang mudah dan murah untuk diakses. Sehingga dapat meningkatkan kepercayaan stakeholder, baik masyarakat maupun investor.

\section{DAFTA R PUSTAKA}

Abdul Halim. 2013. Akuntansi Keuangan Daerah. Salemba Empat: Jakarta

Arik, Susbiyani,et.al,. 2014. The Compliance with Mandotory Disclosure of Financial Statement : A Study from Local Government in Indonesia. Research Journal of Finance and Accounting ISSN 2222-1697 (Paper) ISSN 2222-2847 (Online) Vol.5, No.10, 2014

Chen, et.al,. 2015. Disclosure of Government Financial Information and the Cost of Local Government's Debt Financing-Empirical Evidance from Provincial Investment Bonds for Urban Construction. China Journal of Accounting Research 9 (2016) 191-206. Ghozali, Imam. 2011. Aplikasi Analisis Multivariate 
dengan Program IBM SPSS 20. Badan Penerbit Universitas Diponegoro: Semarang

Hilmi, Amiruddin Zul. 2011. Analisis Faktor - Faktor yang Mempengaruhi Tingkat Pengungkapan Laporan Keuangan Pemerintah Provinsi. Simposium Nasional Akuntansi 2012, Universitas Indonesia: Jakarta

Instruksi Menteri Dalam Negeri Republik Indonesia Nomor 188.52/1797/SJ Tentang Peningkatan Transparansi Pengelolaan Anggaran Daerah (TPAD).

Laswad, F., Fisher, R., \& Oyelere, P. 2005. Determinants of voluntary Internet financial reporting by local government authorities. Journal of Accounting and Public Policy, 24(2), 101-121.

Peraturan Menteri Komunikasi dan Informatika Nomor 28 Tahun 2006 tentang Penggunaan Nama Domain go.id untuk Pemerintah Pusat dan Daerah

Peraturan Pemerintah Republik Indonesia No 56 Tahun 2005 Tentang Sistem Informasi Keuangan Daerah

Peraturan Pemerintah Nomor 38 Tahun 2007 Tentang Pembagian Urusan Pemerintahan, antara Pemerintah, Pemerintah Daerah Provinsi, dan Pemerintah Daerah Kabupaten/Kota

Peraturan Pemerintah Nomor 71 Tahun 2010 tentang Standar Akuntansi Pemerintahan
Rahim, Wanda Mustika dan Martani, Dwi.2012. Analisis Pengaruh Tingkat Akses Internet, Kompetisi Politik, Opini Audit, Karakteristik Pemda, dan Karakteristik Demografi terhadap Pengungkapan Informasi Keuangan dan Non Keuangan Website Pemerintah Daerah. Universitas Indonesia: Jakarta

Rahman, Aditya dkk. 2013. Determinan Internet Financial Local Government Reporting di Indonesia. Simposium Nasional Akuntansi XVI Manado, 2528 September 2013.Universitas Sebelas Maret: Surakarta

Suwardjono. 2014. Teori Akuntansi: Perekayasaan Pelaporan Keuangan. Edisi Ketiga. Yogyakarta: BPFE

Undang-Undang Nomor 15 Tahun 2004 tentang Pemeriksaan Pengelolaan dan Tanggung Jawab Keuangan Negara.

Undang-Undang Republik Indonesia No 32 Tahun 2004 tentang Pemerintah Daerah

Undang-Undang Nomor 23 Tahun 2014 tentang Pemerintahan Daerah

Undang-Undang Republik Indonesia Tahun 1945 Pasal 18 Ayat (1), (2).

www.interface.or.id (Diakses pada 23 Desember 2016) www.jatengprov.go.id (Diakses pada 19 September 2016) 